\title{
Chemical Composition and Ethnobotany of Livistona jenkinsiana Griff: An Endangered Thatching Palm Tree of Eastern Himalayas
}

\author{
Temin Payum*
}

\begin{abstract}
Objectives: To study the uses of various parts and cultivation of Livistona jenkinsiana among tribal people of Arunachal Pradesh in addition to study the chemical composition and the related health benefits if any. Methods: Field survey and interview were used for ethnobotany and GC-MS was used in the studies of chemical compositions. Results: This study reports numbers of volatile and non-volatile compounds from the fruit of Livistona jenkinsiana with various health benefits. Presence of remarkable high percentage of trehalose sugar is reported in this work from the fruit of L. jenkinsiana. The study also reports various uses of the parts of this palm tree as thatching tree, fencing and house construction. The study also reports need of conservation of this bioculturally important endangered and threatened thatching palm tree. Conclusion: L. jenkinsiana is a bioculturally and economically important endangered thatching palm tree. The fruit could be a source of plant originated fats and trehalose sugar. Fifty percent of compounds present in this fruit are useful in various health problems. There should be further scientific studies in the domains of industrial utility of this underutilized palm tree.
\end{abstract}

Key words: Ethnobotany, Thatch, Fruit, Phytochemical, Trehalose, Indigenous People, Himalayas, Biocultural.

\section{INTRODUCTION}

\section{Temin Payum*}

Jawaharlal Nehru College, Pasighat, East Siang D, Arunachal Pradesh, INDIA.

Correspondence

Temin Payum

Jawaharlal Nehru College, Pasighat, East Siang D, Arunachal Pradesh, INDIA.

Phone no: +91 7308461524

E-mail: teminpayum519@gmail.com

History

- Submission Date: 26-05-2018;

- Review completed: 09-07-2018;

- Accepted Date: 18-07-2018

DOI : 10.5530/pj.2018.6.206

Article Available online

http://www.phcogj.com/v10/i6

\section{Copyright}

(c) 2018 Phcog.Net. This is an openaccess article distributed under the terms of the Creative Commons Attribution 4.0 International license.

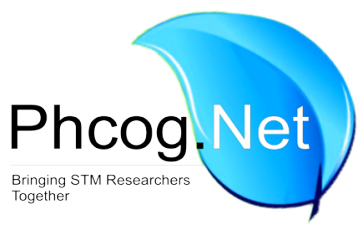

Northeastern regions of India is considered as one of the biodiversity hot spot and abode of the Indian cultural diversity and repository. ${ }^{1-2}$ Tribal people of Arunachal Pradesh use natural resources in almost all aspects of their life. For instance, Food they eat is collected from forest, medicine they use is collected from forest and house they stay is also constructed by using materials collected from forest. People live in Arunachal Pradesh, an Indian state lie in the Eastern Himalayas use innumerable plant resources in day to day life. Livistona jenkinsiana Griff.; an endangered and threatened species is used in many useful purposes. To study the ethnobotany of this tree and also the chemical composition of the edible part of fruit of this tree, present study was carried out.

Livistona jenkinsiana Griff. is an endangered and threatened species in Indian continent and globally too. $^{3-7}$ Livistonia species has a wide distribution; distributed in Africa, South Arabia, South East and Eastern Asia, Malaysia and Australia, China and Thailand. L. jenkinsiana was first described by William Griffith in 1845 from collection made in 1842 by Major Francis Jenkins from Nowgaon, Assam, ${ }^{8}$ the type specimen is still available in the National Botanical Garden of Belgium. ${ }^{9}$ While, this palm tree is bio-culturally indispensable for the indigenous people of Arunachal Pradesh, this tree is practically the "Kalpvriksha of Arunachal Pradesh. ${ }^{10-11}$ However, no detail work has yet been done on this important tree in relation to the local people of Arunachal Pradesh except a limited report on Adi community, ${ }^{11}$ while this palm tree is one of the most important and indispensable biocultural tree of these regions. Field visit, questionnaire, personal observation, interview are some useful input to research ethnobotany while GC-MS is one of the advanced tools to study chemical compositions of biological origin. The present study was carried out to study the uses of different parts of L. jenkinsiana by using Field visit, questionnaire, personal observation and interview and the chemical composition of the fruit was studied by using GC-MS analysis.

GC-MS is highly effective and versatile analytical techniques with numerous scientific applications to cater the field of applied Sciences and Technology. It is a very useful for quality control, analytical research, impurity profiling and maintenance for human welfare and development, ${ }^{12}$ GC-MS enhanced molecular ion, improved confidence in sample identification, significantly increased range of thermally labile and low volatility samples amenable for analysis, much faster analysis, improved 
sensitivity particularly for compounds that are hard to analyze and the many other features and options provide compelling reasons to use the GC-MS in broad range of areas. ${ }^{13-14}$ Foods and beverages have several aromatic compounds existing naturally in native state or formed while processing and GC-MS is exclusively used for the analysis of esters, fatty acids, alcohols, aldehydes, terpenes etc, It is used in the analysis of piperine, spearmint oil, lavender oil, essential oil, fragrance reference standards, perfumes, chiral compounds in essential oils, fragrances, menthol, allergens, olive oil, lemon oil, peppermint oil, yiang oil, straw berry syrup, butter triglycerides, residual pesticides in food and wine. ${ }^{15-16}$

\section{MATERIALS AND METHODS}

\section{Plant material}

L. jenkinsiana is erect and unbranched crowned with leaves, attains about $25 \mathrm{~m}$ (Figure 1). Leaves are palmate, long petiole with spines, inflorescence are axillary and interfoliar, spathe is redish brown and hard. Flowers creamy white, fruit drupe and copper brown colour, flowering February-March. The ethnobotany was taken from personal experiences, observations, field survey, interactions and interviews in the Upper Siang District, Lower Siang District and West Siang District of Arunachal Pradesh, a total of twenty five villages were visited in which 130 villagers including thirty teenager and fifty adult each woman and man were participated in interview. Fruit (Figure 2) was collected from my own farm of Sille Village of East Siang District of Arunachal Pradesh.

\section{Preparation of extract}

The mature fruit of $L$. jenkinsiana was collected in the month of February and kept for two weeks to ripe in a shade place of house by wrapping in a polygene bag. The ripe sample was separated from stony seed/nut and shade dried then pulverized into powder by using a grinder. $500 \mathrm{~g}$ of sample powder of was soaked in ethanol (Merck) for $72 \mathrm{~h}$ with intermittent shaking then filtered through Whatmann No. 41 filter paper and concentrated on water bath to get semi solid mass/extract.

\section{GC-MS Analysis}

Gas-Chromatography Mass Specrometry (GC-MS) analysis of the ethanol extracts of J. livistona was carried out in Shimadzu GC-MS-QP-2010 plus system. RTx-5 Sil MS column (30 m X 0.25 mm id X 0.25 film thickness) was used for the analysis. The operating conditions of the column were as follows:

Oven temperature program from $80^{\circ} \mathrm{C}$ to $210^{\circ} \mathrm{C}$ at $4^{\circ} \mathrm{C} / \mathrm{min}$ withhold time of $2 \mathrm{~min}$ and from $210^{\circ} \mathrm{C}$ to $300^{\circ} \mathrm{C}$ at $15^{\circ} \mathrm{C} / \mathrm{min}$ withhold time of $5 \mathrm{~min}$, and the final temperature was kept for $20 \mathrm{~min}$. The injector temperature was maintained at $270^{\circ} \mathrm{C}$, the volume of injected sample was $0.3 \mu \mathrm{l}$; pressure $85.4 \mathrm{kPa}$, total flow $76.8 \mathrm{~mL} / \mathrm{min}$, column flow 1.21 $\mathrm{mL} / \mathrm{min}$, linear velocity $40.5 \mathrm{~cm} / \mathrm{sec}$, purge flow $3.0 \mathrm{~mL} / \mathrm{min}$, split ratio: 60.0 ; ion source temperature $230^{\circ} \mathrm{C}$; scan mass range of $\mathrm{m} / \mathrm{z} 40-600$ and interface line temperature $280^{\circ} \mathrm{C}$. The identification of compounds was performed by comparing their mass spectra with data from NIST 11 (National Institute of Standards and Technology, US) and WILEY 8.

\section{Identification of Phyto composition}

The identification of compounds was performed by comparing their mass spectra with data from NIST 11 (National Institute of Standards and Technology, US) and WILEY 8.

\section{RESULTS}

Use of leaves: Matured leaves are the main part that is used in thatching local house (Figure 3), grain store house (Figure 4), cow shed, piggery shed and rest house of jhum cultivation as well as in wet cultivation

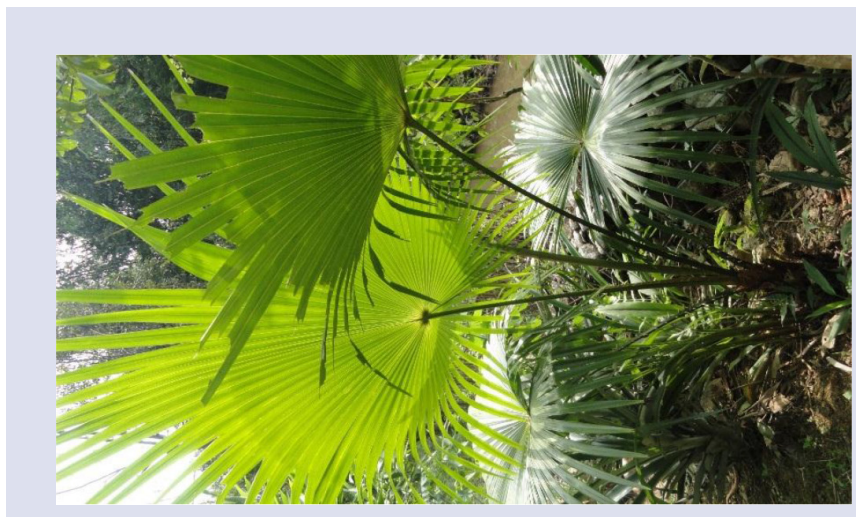

Figure 1: L. jenkinsiana

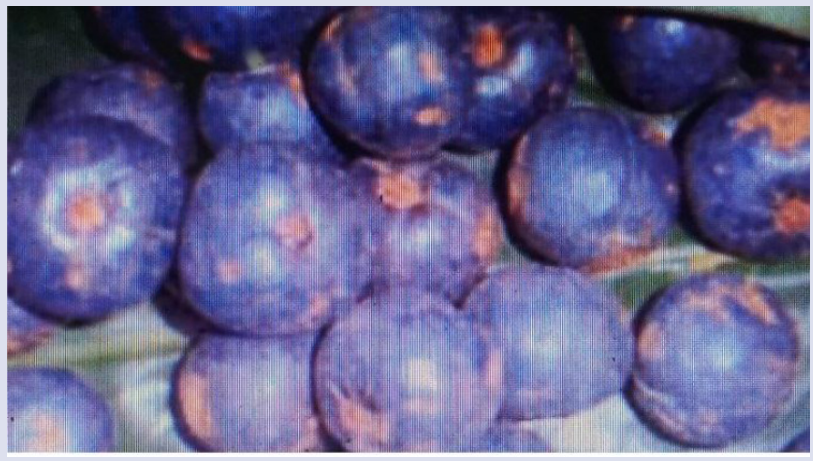

Figure 2: Fruit

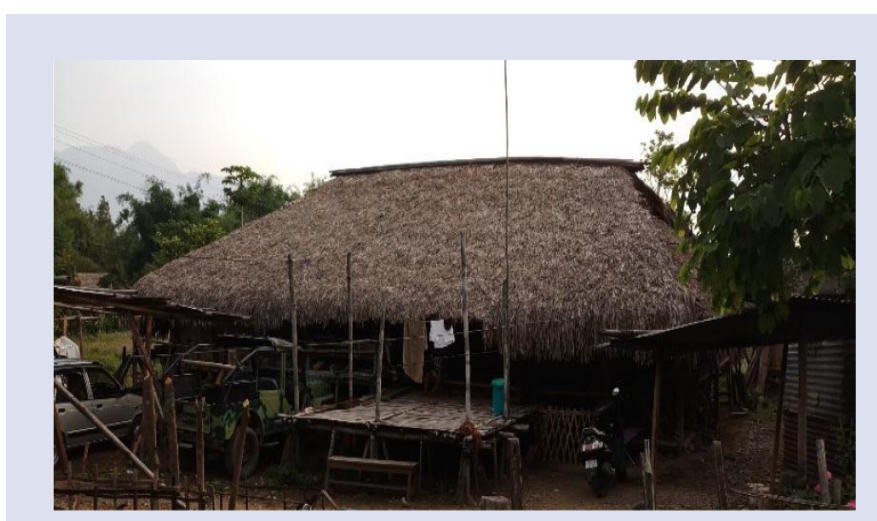

Figure 3: Local House.

farm. Usually, Tender leaves are also used in making bangles for girls as attire and also as a broom. Leaves with stalk is used as an umbella in rainy days, it is also used in making an article called ebong/obo/botok in local dialect to protect the farmers from rain and sun when they work in farm. In practice, leaves are not collected in the full moon period to avoid damage made from insects; collected leaves are piled and allowed to dry before thatching. A typical local house needs at least 2500 leaves. 


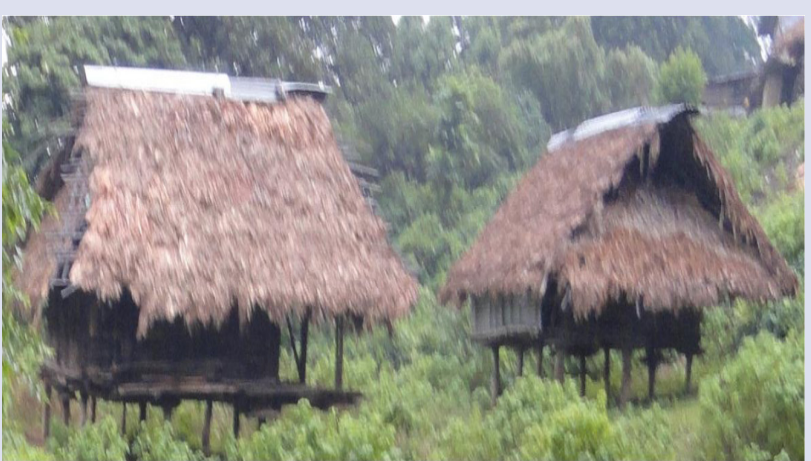

Figure 4: Grainery house thatching.

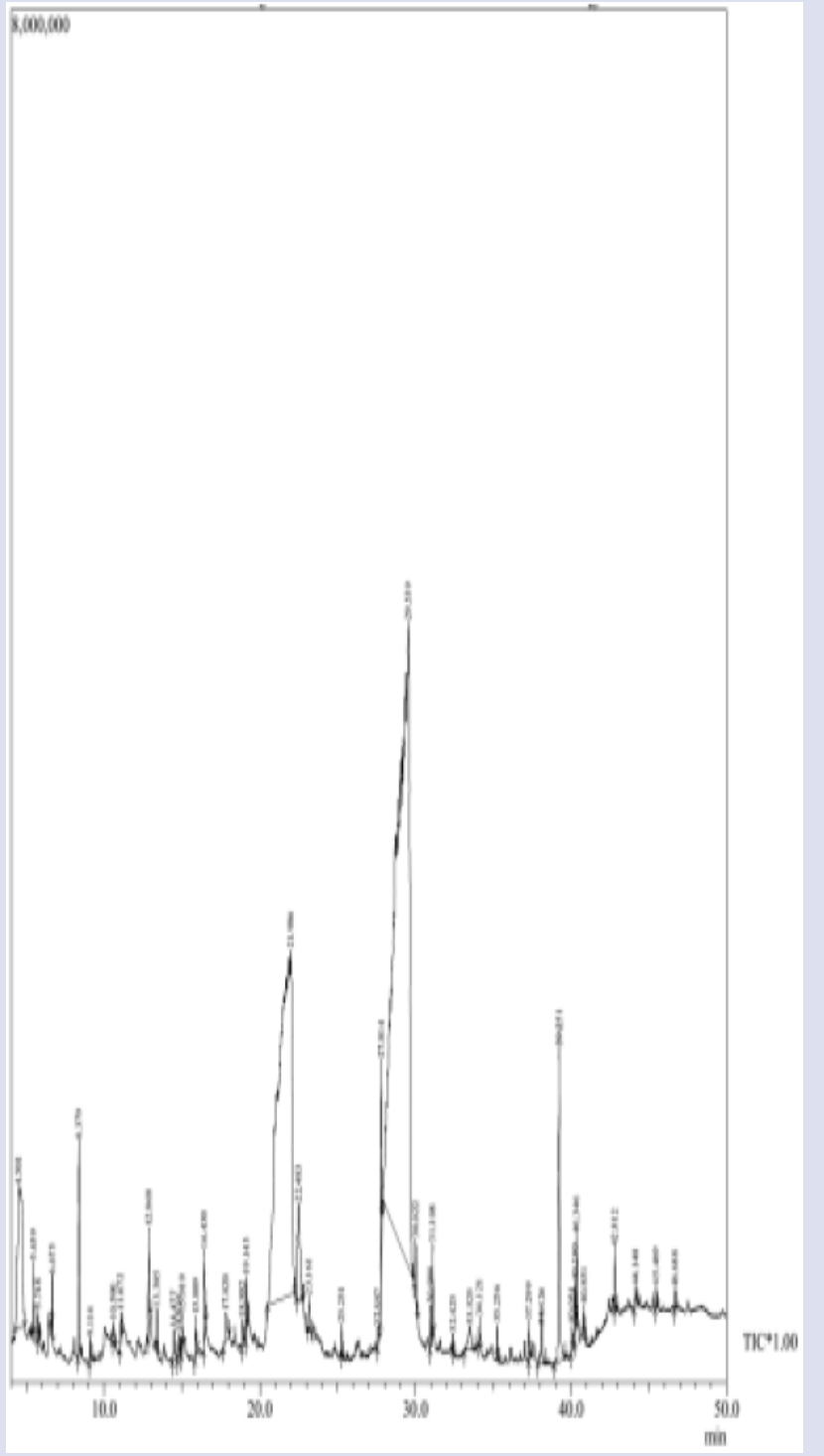

Figure 5: GC-MS peak of ethanolic extract of $L$. jenkinsiana fruit.

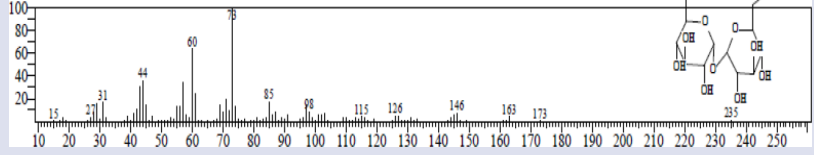

Figure 6: Fragmentation pattern of Trehalose.

Use of stalk: The stalk is used as firewood, fencing construction and as a rope.

Use of trunk: The trunk is used in making floor of local house, as pillar and also in fencing construction.

Use of fruit: The fruit is collected and allowed to ripe, fruit is full of oil and fats; it is consume raw or mix with salt and chilly in Pyrenium leaf and cook by keeping it over the fire place. Seed part is chew with pan.

As a means of livelihood: A field survey at Pasighat town- the oldest and biggest town of all the studied area gave a data that there are five dealers from which buyers of the town dwellers buy their requirements to construct local house, kitchen, cow shed, piggery shed, rest house etc. Current rate was recorded at two rupee and fifty paisa per piece of leaf.

Plantation: Seed propagation is easy and germination rate is almost 100 percent, Villagers sow the seed in the month of February, March and April; good germination rate of seed has been seen when seed is sow at 2 to 3 inches under the soil. Usually clearance of forest is not necessary to sow the seed. This tree is suitable for multiple cropping and almost all household have farm of Livistona tree in village. This tree is also planted on boundary to demarcate the boundary. Interview, interaction and questionnaire revealed that knowledge on the uses and importance on Livistona jenkinsiana plant as a thatching plant is cent percent among all participants irrespective of age and gender which reflects the popularity, importance and utility of this palm tree in the studied area.

Chemical composition: The TIC peak (Figure 5) ethanol extract of L. jenkinsiana fruit contain forty three compounds (Table 1) out of which 22 compounds(Table 2 ) have been reported to be useful and biologically active against numbers of health problems like anticancer, antioxidant, prevention of uric acid formation etc (Table 2). Out of forty three compounds, Trehalose (Figure 6) occupied forty percent in the TIC peak area percentage, trehalose is an energy source.

\section{DISCUSSION}

Livistona jenkinsiana is a useful biocultural plant; this tree ia also a means of livelihood for farmers, it is rare as well as endangered. Propagation is not the major constraint to conserve this important biocultural plant but there is need of awareness and education. Almost all parts of this palm tree is useful. In various parts of the county poor people thatch their houses by using wild musa leaves or cane leaves which are difficult to handle and does not last long, while Livistona jenkinsisna leaves last long and could be an alternative. Modern restaurants and rest house can be given natural touch with cooling effects by using the leaves of this plant which has potential to attract customers and tourists. Decorative and household items like hat, broom and ebong could be introduced in rural market to curve out a means of livelihood. The ethanol extract of L. jenkinsiana fruit contain forty three compounds out of which 22 compounds have been reported to be useful and biologically active against numbers of health problems like anticancer, antioxidant, prevention of uric acid formation etc. Trehalose is an energy source and also a protectant against the effects of freezing or dehydration, an attractive ingredient in food, health and beauty and pharmaceutical products. ${ }^{17}$ commercially available in therapeutic products, including Herceptin ${ }^{\oplus}$, Avastin ${ }^{\circledR}$, Lucentis ${ }^{\oplus}$, 
Table 1: Chemical compositions of the ethanol extract of $L$. jenkinsiana fruit.

\begin{tabular}{|c|c|c|c|c|}
\hline Peak & R. time & Area & Area\% & Name \\
\hline 1 & 4.501 & 17438503 & 4.30 & Digyycerol \\
\hline 2 & 5.459 & 1002351 & 0.25 & 1-Hexanol, 2 Ethyl \\
\hline 3 & 5.478 & 463513 & 0.11 & 1,4-Dimethylpiperazine \\
\hline 4 & 6.675 & 738826 & 0.18 & 1,3,5-Triazine-2,4,6-Triamine \\
\hline 5 & 8.375 & 3500281 & 0.86 & 2,3-Dhydro-3,5-Dihyroxy-6-Methyl-4H-Pyran \\
\hline 6 & 9.114 & 433866 & 0.11 & Ethyl hydrogen succunate \\
\hline 7 & 10.590 & 607620 & 0.15 & 5-Hydroxymethyfurfural \\
\hline 8 & 11.072 & 732465 & 0.18 & 1,3-diacetin \\
\hline 9 & 12.868 & 1839805 & 0.46 & 2-methoxy-4-vinylphenol \\
\hline 10 & 13.385 & 780543 & 0.19 & DL-Malic acid, bis (trimethylsilyl) ester \\
\hline 11 & 14.477 & 1042359 & 0.26 & Ethyl. beta.-d-riboside \\
\hline 12 & 14.814 & 671002 & 0.17 & Ethyl pentofuranoside \\
\hline 13 & 15.010 & 634749 & 0.16 & 1-Phenyl-1-(trimethylsilyloxy)ethylene \\
\hline 14 & 15.889 & 650768 & 0.16 & Trimethyl(1-phenylethanyloxy) s \\
\hline 15 & 16.430 & 2127914 & 0.52 & 2-Hydroxy-5-Methylisopthalaldehyde \\
\hline 16 & 17.820 & 1809745 & 0.45 & .beta.-D-glucosyloxymethane \\
\hline 17 & 18.882 & 769173 & 0.19 & Adipic acid, trimethylsilyl ester \\
\hline 18 & 19.143 & 840859 & 0.21 & Phenol, (1,1-Dimethylethyl)--Methoxy \\
\hline 19 & 21.986 & 120477428 & 29.70 & Ethyl.alpha.-d-glucopyranoside \\
\hline 20 & 22.483 & 5917995 & 1.46 & Methyl 6-O-[1-Methylpropyl]-.beta.-d-galactopyranoside. \\
\hline 21 & 23.161 & 887158 & 0.22 & 4-((1E)-3-Hydroxy-1-prpenyl)-2-Methoxyphenol \\
\hline 22 & 25.251 & 437934 & 0.11 & 1-Hydroxydihydrosafrole Trimethylsilyl ether \\
\hline 23 & 27.597 & 401760 & 0.10 & Dibutyl phthalate \\
\hline 24 & 27.814 & 3698879 & 0.91 & Hexadecanoic acid \\
\hline 25 & 29.539 & 213299058 & 52.58 & Trehalose \\
\hline 26 & 30.022 & 2134323 & 0.53 & Mycose \\
\hline 27 & 30.980 & 697998 & 0.17 & 9.12-Octadecanoic acid (Z,Z)- \\
\hline 28 & 31.108 & 1430656 & 0.35 & Cis-Vaccinic acid \\
\hline 29 & 32.425 & 336162 & 0.08 & Trimethylsilyl (9E)-9-Octdecenote \\
\hline 30 & 33.525 & 2037107 & 0.50 & Benzyl.beta.-d-glucoside \\
\hline 31 & 34.121 & 509333 & 0.13 & 4-(2-Methoxyethyl)phenol \\
\hline 32 & 35.256 & 274975 & 0.07 & Guaiacol,4-ethyl- \\
\hline 33 & 37.299 & 684878 & 0.17 & Palmitin,2-mono \\
\hline 34 & 38.126 & 1643896 & 0.41 & Bis(Trimethylsilyl)Methylphosphonate \\
\hline 35 & 39.251 & 9656375 & 2.38 & 5-Chlorovaleramide, N-(2,4-dimethoxyphenyl)- \\
\hline 36 & 40.054 & 684385 & 0.17 & 6-Hydroxy-3-(3,5-dimethoxyphenyl)benzo (B) furan \\
\hline 37 & 40.280 & 510862 & 0.13 & 9,12-Octadecadienoyl Chloride, (Z,Z)- \\
\hline 38 & 40.364 & 1126216 & 0.28 & Oleoyl Chloride \\
\hline 39 & 40.851 & 308977 & 0.08 & Ergostane \\
\hline 40 & 42.812 & 937921 & 0.23 & Hinokiol \\
\hline 41 & 44.148 & 702390 & 0.17 & Silicone oil \\
\hline 42 & 45.469 & 382718 & 0.09 & Coniferyl alcohol, dihydrodi \\
\hline \multirow[t]{2}{*}{43} & 46.688 & 401628 & 0.10 & gamma.-sitosterol \\
\hline & & 405665354 & 100.00 & \\
\hline
\end{tabular}


Table 2: Reported biological activity and useful compounds.

\begin{tabular}{|c|c|c|}
\hline Peak & Name & Activity \\
\hline 1 & Digyycerol & Antibacterial ${ }^{17}$ \\
\hline 5 & 2,3-Dhydro-3,5-Dihyroxy-6-Methyl-4H-Pyran & Anti-HIV- integrase ${ }^{*}$ \\
\hline 10 & DL-Malic acid, bis (trimethylsilyl) ester & Iinhibit production of uric acid ${ }^{*}$ \\
\hline 11 & Ethyl. beta.-d-riboside & Coronary dilator, antidote ${ }^{*}$ \\
\hline 14 & Trimethyl(1-phenylethanyloxy) s & Smart dug, antin cancer, anti dote ${ }^{*}$ \\
\hline 15 & 2-Hydroxy-5-Methylisopthalaldehyde & Testosterone hydroxylase inducer ${ }^{*}$ \\
\hline 17 & Adipic acid, trimethylsilyl ester & Inhibit production of uric acid, Acidifier* \\
\hline 19 & Ethyl.alpha.-d-glucopyranoside & CNS depressant, smart drug* \\
\hline 21 & 4-((1E)-3-Hydroxy-1-prpenyl)-2-Methoxyphenol & Cancer preventive* \\
\hline 24 & Hexadecanoic acid & Inhibit production of uric acid ${ }^{*}$ \\
\hline 25 & Trehalose & $\begin{array}{l}\text { An energy source or a protectant against the effects of freezing or dehydration, an } \\
\text { attractive ingredient in food, health and beauty and pharmaceutical products. }{ }^{18} \\
\text { commercially available in therapeutic products, including Herceptin }{ }^{\circ} \text {, Avastin }{ }^{8} \text {, Lucentis } \\
\text { and Advate }{ }^{\circ}{ }^{19} \text { Prevent oral dryness caused by dental treatment, }{ }^{20} \text { a unique sugar capable } \\
\text { of protecting biomolecules against environmental stress, Trehalose has a key role in the } \\
\text { survival of some plants and insects, termed anhydrobionts, in harsh environments, even } \\
\text { when most of their water body is removed, it proved to be an active stabilizer of enzymes, } \\
\text { proteins, biomasses, pharmaceutical preparations and even organs for transplantation. }{ }^{21}\end{array}$ \\
\hline 27 & 9.12-Octadecanoic acid (Z,Z)- & $\begin{array}{l}\text { Acidifier, inhibit production of uric acid, Increase Aromatic Amino Acid Decarboxylase } \\
\qquad \text { Activity }^{*}\end{array}$ \\
\hline 28 & Cis-Vaccinic acid & Inhibit production of uric acid ${ }^{*}$ \\
\hline 29 & Trimethylsilyl (9E)-9-Octdecenote & Anticancer ${ }^{*}$ \\
\hline 30 & Benzyl.beta.-d-glucoside & Cancer preventive, CNS depressant, antidote, smart drug* \\
\hline 33 & Palmitin,2-mono & Monoamine precursor ${ }^{*}$ \\
\hline 36 & 6-Hydroxy-3-(3,5-dimethoxyphenyl)benzo (B) furan & Anticancer, antidote ${ }^{*}$ \\
\hline 37 & 9,12-Octadecadienoyl Chloride, (Z,Z)- & Increase zinc bioavailability ${ }^{\star}$ \\
\hline 39 & Ergostane & $\begin{array}{c}\text { Anticancer, antioxidant, anti-inflammatory, anti-angiogenesis, liver protection and } \\
\text { radioprotection activities. }{ }^{22}\end{array}$ \\
\hline 40 & Hinokiol & Antiinflamatory. ${ }^{23}$ \\
\hline 42 & Coniferyl alcohol, dihydrodi & Detaxicant of alcohol ${ }^{*}$ \\
\hline 43 & gamma.-sitosterol & $\begin{array}{l}\text { Antagonist*, Antimalarial, antifungal, Antioxidant, Anti-diabetic, Anti-angeogenic, } \\
\text { Anticancer, antimicrobial, anti-inflammatory, antidiarrhoeal and antiviral. }{ }^{24}\end{array}$ \\
\hline \multicolumn{3}{|c|}{ *https://phytochem.nal.usda.gov/phytochem/chemicals/show/6193?et= } \\
\hline
\end{tabular}

and Advate ${ }^{\oplus}{ }^{18}$ Prevent oral dryness caused by dental treatment, ${ }^{19}$ a unique sugar capable of protecting biomolecules against environmental stress, Trehalose has a key role in the survival of some plants and insects, termed anhydrobionts, in harsh environments, even when most of their water body is removed, it proved to be an active stabilizer of enzymes, proteins, biomasses, pharmaceutical preparations and even organs for transplantation. ${ }^{20}$ Digyycerol is Antibacterial, ${ }^{21}$ 2,3-Dhydro-3,5-Dihyroxy-6-Methyl-4H-Pyran is Anti-HIV- integrase*, DL-Malic acid, bis (trimethylsilyl) ester inhibit production of uric acid*, Ethyl. beta.-driboside is Coronary dilator, antidote ${ }^{\star}$, Trimethyl(1-phenylethanyloxy) s is a Smart dug, antin cancer, anti-dote ${ }^{\star}, 2$-Hydroxy-5-Methylisopthalaldehyde is Testosterone hydroxylase inducer ${ }^{\star}$, Adipic acid, trimethylsilyl ester is Inhibit production of uric acid, Acidifier*, Ethyl.alpha.-d-glucopyranoside is a smart drug*, 4-((1E)-3-Hydroxy-1-prpenyl)-2-Methoxyphenol is Cancer preventive*, Hexadecanoic acid Inhibit production of uric acid*, 9.12-Octadecanoic acid (Z,Z)- is an Acidifier, inhibit production of uric acid, Increase, Aromatic Amino Acid Decarboxylase Activity ${ }^{*}$, Cis-Vaccinic acid Also Inhibit production of uric acid*, Trimethylsilyl (9E)-9-Octdecenote is Anticancer ${ }^{\star}$, Benzyl. beta.-d-glucoside is a Cancer preventive, CNS depressant, antidote, smart drug*, Palmitin,2-mono is Monoamine precursor ${ }^{\star}$, 6-Hydroxy-3-(3,5-dimethoxyphenyl)benzo (B) furan is an Anticancer, antidote ${ }^{\star}$ 9,12-Octadecadienoyl Chloride, (Z,Z)Increase zinc bioavailability ${ }^{*}$ Ergostane is an Anticancer, antioxidant, anti-inflammatory, anti-angiogenesis, liver protection and radioprotection activities, ${ }^{22}$ Hinokiol is an Antiinflamatory, ${ }^{23}$ Coniferyl alcohol, dihydrodi is Detaxicant of alcohol* ${ }^{*}$.gamma.-sitosterol is Antagonist*, Antimalarial, antifungal, Antioxidant, Anti-diabetic, Anti-angeogenic, Anticancer, antimicrobial, anti-inflammatory, anti-diarrheal and antiviral. ${ }^{24}$ This palm tree is a bioculturally important tree and inseparable from the day to day life of the tribal people of Arunachal Pradesh. The fruit has potential of a major source of trehalose sugar (Figure 5); there is need of propagation, cultivation, farming and exploration of oil of this important palm tree.

\section{ACKNOWLEDGEMENT}

Author would like to thank Principal and Institutional Biotech Hub, JN College Pasighat for Laboratory Permission and Facility. 


\section{CONFLICT OF INTEREST}

The authors declare no conflict of interest.

\section{ABBREVIATIONS}

GC-MS: Gas chromatograpgy mass spectrometry; L.jenkinsiana: Livistona jenkinsiana.

\section{REFERENCES}

1. Myer N, Muttermeier CA, Fornseca GAB, Kent J. Biodiversity hotspots for conservation priorities. Nature. 2000;403(6772):853-8.

2. Singh RK. Agrobiodiversity: conserving diversity and culture-Pem Dolma. Honey Bee. 2004;15:12-3.

3. Rolla SR, Joseph J. Livistona jenkinsiana. Principles. 1962;6(3):103-6.

4. Anonymous: Red Data Book of Indian Plants. 1987;1-3, BSI Kolkata.

5. Srivastava RC. The state tree of Arunachal Pradesh. Current Science. 2006;91(7):857.

6. FAO: Threatened South Asian Palms, FAO Rome. http://www.org./

7. Aparajita D, Rawat GS. Dispersial mode of spatial patterns of tree species in a tropical forest in Arunachal Pradesh, North East India. Trop Conserv. 2008;1(3):163-85.

8. Bhuyan, Bhuyan BK. Pioneer of Assam Tea Industry Maj General Francis Jenkins. Poosowa. 2006;34(11):7.

9. Barfod AS, Dowe JL, Suksathan P. Major Jenkins Fan Palms in Thailand. Palms. 2010;54(3):109-18.

10. Srivastava RC. The state tree of Arunachal Pradesh. Current Science. 2006;91(7):857.

11. Singh RK, Srivastava RC, Mukherjee TK. Adi Community: Toko-patta (Livistona jenkinsiana Griff.: Adi community and conservation of culturally important endangered tree species in eastern Himalaya. Indian Journal of Traditional Knowledge. 2010;9(2):231-24.

12. Chauhan A, Goyal MK, Chauhan P. GC-MS Technique and its Analytical Applica- tions in Science and Technology. Journal of Analytical and Bioanalytical. 2014; Techniques. 5:222. doi: 10.4172/2155-9872.1000222

13. International Organization for Standardization: Quality management systemsFundamentals and vocabulary. 2002; ISO 9000:2000(E).

14. ISO 9000:2000(E).., ISO/IEC 17025: General Requirements for Competence of Testing and Calibration Laboratories. Paragraphs. 2005;5.5-5.6.

15. Alon T, Amirav A. Isotope abundance analysis methods and software for improved sample identification with supersonic gas chromatography/mass spectrometry. Rapid Commun Mass Spectrom. 2006;20:2579-88.

16. Robert P, Adams. Identification of Essential Oil Components By Gas Chromatography/Mass spectrometry. 2007; $4^{\text {th }}$ edition, Allured Pub Corp.

17. Richards AB, Krakowka S, Dexter LB, Schmid H, Wolterbeek APM, Berendsen $\mathrm{DHW}$, et al. Trehalose: a review of properties, history of use and human tolerance, and results of multiple safety studies. Food and Chemical Toxicology. 2002;40(7):871-98.

18. Satoshi O, John WY. Trehalose: Current Use and Future Applications. Journal of Pharmaceutical Sciences. 2011;100(6):2020-53.

19. Mori Y, Yano F, Shimohata N, Suzuki S, Chung UI, Takato T. Trehalose inhibits oral dryness by protecting the cell membrane. International Journal of Oral and Maxillofacial Surgery. 2010;39(9):916-21.

20. Chiara S, Isabella DL, Mario DR. Trehalose production: Exploiting novel approaches. Trends in Biotechnology. 2002;20(10):420-5.

21. Yamazaki K, Yamamoto T, Noriolnoue YK. Enhancement of antilisterial activity of essential oil constituents by nisin and diglycerol fatty acid ester. Food Microbiology. 2004;21(3):283-9.

22. Wang, et al. Intestinal Absorption of Ergostane and Lanostane Triterpenoids from Antrodia cinnamomea Using Caco-2 Cell Monolayer Model. Nat Prod Bioprospect. 2015;5(5):237-46.

23. Fan, et al. The anti-inflammatory activities of an extract and compounds isolated from Platycladus orientalis (Linnaeus) Franco in vitro and ex vivo. Journal of Ethnopharmacology. 2012;141(2):647-52.

24. Venkata RB, et al. Antibacterial, Antioxidant Activity and GC-MS Analysis of Eupatorium odoratum. Asian Journal of Pharmaceutical and Clinical Research. 2012;5(2):99-106.
GRAPHICAL ABSTRACT

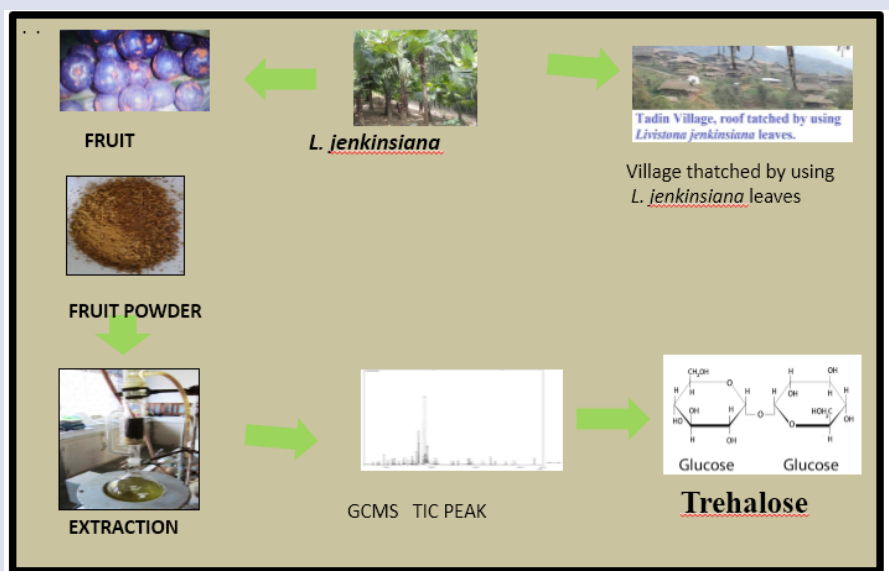

\section{ABOUT AUTHORS}

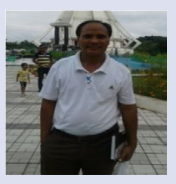

Temin Payum obtained his Ph.D degree in 2015 from Rajiv Gandhi University, Itanagar. Currently he is working as Assistant Professor at Jawaharlal Nehru College, Pasighat, Department of Botany, Arunachal Pradesh, India. He is works on Ethnobotany, Anti oxidants, Proximate, Pharmacognosy and Phytochemisty on the medicinal food plants used among Tribal people of Arunachal Pradesh. He also works on Biocultural plants and natural body cleanser plants.

Cite this article: Payum T. Chemical Composition and Ethnobotany of Livistona jenkinsiana Griff: An Endangered Thatching Palm Tree of Eastern Himalayas. 2018;10(6):1202-7. 